\title{
SITE INVESTIGATION FOR CONSTRUCTION OF EMERGENCY SPILLWAY AT THE JATIGEDE DAM
}

\author{
Gusti Warman and I Gde Budi Indrawan* \\ Geological Engineering Department, Faculty of Engineering, Gadjah Mada University, Yogyakarta, Indonesia
}

\begin{abstract}
An emergency spillway has been planned to be constructed at the Jatigede Dam, West Java, to allow floodwater to flow downstream and to prevent the capacity of the main spillway to be exceeded during large flood events. The complex geology of the Jatigede Dam area, however, poses a challenge to determine the suitable location for the emergency spillway construction, either in the area to the west or to the east of the embankment dam. An engineering geological mapping and landslide susceptibility zoning were conducted to determine the engineering geological characteristics of the area surrounding the Jatigede Dam. The site investigation showed that the area to the west of the embankment dam tended to have a lower slope inclination than the area to the east of the embankment dam. Both areas to the west and to the east of the embankment dam were found to be composed of less erosion resistant rock units. The existence of the earth retaining structures for slope stabilization in the area to the east of the embankment dam will, however, likely limit the flexibility in developing the emergency spillway route. With respect to the existence of fault systems, both areas to the west and to the east of the embankment dam will likely be influenced by similar conditions. The area to the west of the embankment dam tended to be less susceptible to landslide as compared to the area to the east of the embankment dam. The undeveloped land use of the area to the west of the embankment
\end{abstract}

*Corresponding author: IG.B. INDRAWAN, Geological Engineering Department, Faculty of Engineering, Gadjah Mada. Jl. Grafika 2 Yogyakarta, Indonesia. E-mail: igbindrawan@ugm.ac.id dam as compared to the area to the east of the embankment dam will provide more flexibility in construction of the emergency spillway. Due to the more favorable engineering geological conditions, the area to the west of the embankment dam is proposed for the location of the emergency spillway construction.

Keywords: Emergency spillway, Engineering geological mapping, Jatigede Dam

\section{Introduction}

A spillway is an essential feature of a dam that is constructed to pass flood water safely downstream when the reservoir is overflowing (Novak et al., 2007). Dams typically consist of two spillways, which are main and emergency spillways. The main spillway maintains normal water level in the reservoir. Meanwhile, the emergency spillway is designed to operate during emergency conditions, particularly when the main spillway fails to fully operate during extreme flood events or when the capacity of the main spillway has been exceeded, to prevent overtopping of the dam.

The Jatigede Dam is an embankment dam and located in the Cimanuk Watershed, Sumedang Regency, West Java Province, Indonesia. Discharge measurements conducted at the Rentang Weir, which was located downstream from the embankment dam, showed that discharge of the Cimanuk River could reach up to $1,004 \mathrm{~m}^{3} / \mathrm{s}$ (PT. Indra Karya Consulting Engineer, 2013). The main spillway of the embankment dam consists of four radial type gates and is designed based on a 
$11,000 \mathrm{~m}^{3} / \mathrm{s}$ probable maximum flood (PMF) discharge (PT. Indra Karya Consulting Engineer, 2013). Maximum discharge capacity of the main spillway is about $58.76 \%$ of the total discharge capacity. When all four or, at least, three gates of the main spillway operate in maximum flood events, the water level of reservoir is expected to be under the freeboard. However, when only two gates operate normally in maximum flood events, the water level of reservoir is estimated to exceed the freeboard. To ensure the safety of the embankment dam during extremely large flood events, an emergency spillway is, therefore, required.

The possible locations for the emergency spillway construction are around the periphery of the water reservoir, either in the area to the west or to the east of the embankment dam. The flood water is then released to the Cimanuk River downstream behind the embankment dam. As the Jatigede Dam and the surrounding area are composed of complex geology (Makmur, 2013), a detailed site characterization is required to ensure the planned emergency spillway will not be affected by the existing and future geological conditions.

The Jatigede Dam area is located at the eastern part of Bogor Anticlinorium having an eastwest fold axis (van Bemmelen, 1949). According to the Regional Geological Map of the Arjawinangun Sheet (Djuri, 1995), the oldest rock unit deposited in the research area was a sandstone intercalated with shale of the Upper Oligocene to Oligo-Miocene Cinambo Formation. Subsequently, it was deposited a volcanic breccia of the Lower Part of the Lower to Upper Miocene Halang Formation, a claystone of the Upper Part of the Lower to Upper Miocene Halang Formation, a claystone intercalated with tuffaceous sandstone of the Upper Part of the Lower to Upper Miocene Halang Formation, a tuff breccia of the Lower Quartenary Folded Breccia Formation, a volcanic breccia of the Middle Quartenary Undifferentiated Old Volcanic Products, and a clayey sand of the Recent Alluvial and Talus Deposits. In addition to the complex lithologies, the Jatigede Dam area has also a complex tectonic history (Makmur, 2013).
This paper presents results of site investigation to determine the most suitable location for construction of an emergency spillway at the Jatigede Dam. The engineering geological characteristics of the areas to west and to east of the embankment dam are presented and compared.

\section{Methodology}

An engineering geological mapping was conducted to determine the engineering geological characteristics of the areas surrounding the embankment dam. Data of morphology, soil and rock physical and engineering properties, geological structure, seepage, vegetation, and land use were collected during the site investigation and drawn in 1:25,000-scale topographic maps. Rock weathering degrees were determined following the classification by ISRM (1981). Data of rainfall and earthquake frequency were collected from existing reports of previous site investigations. A landslide susceptibility zoning was then conducted following the Regulation of Indonesian Minister of Public Works No. 22/PRT/M/2007 (Departemen Pekerjaan Umum, 2007). Two groups of landslide-controlling parameters are considered in the regulation, which are natural conditions and human activities. However, the parameters of natural conditions were only considered in this research since human activities in the area surrounding the embankment dam were relatively low. The landslide-controlling parameters used in the landslide susceptibility zoning included slope inclination, soil cover, rock slope, rainfall intensity, seepage, earthquake frequency, and vegetation. Each of those landslide-controlling parameters was given a different susceptibility weight and classified into a 1,2, or 3 susceptibility class, indicating a low, moderate, or high class of susceptibility to landslide, respectively. A susceptibility index of each parameter to landslide was then calculated by multiplying the weight by the class. The rating criteria in the landslide susceptibility zoning are shown in Table 1 .

The conditions of slope inclination, soil cover, and rock slope in the research area varied and could be categorized into low to high classes 
Table 1: Rating criteria in landslide susceptibility zoning (Departemen Pekerjaan Umum, 2007).

\begin{tabular}{|c|c|c|c|c|c|}
\hline \multirow{2}{*}{ No. } & \multirow{2}{*}{ Parameter } & \multirow{2}{*}{ Weight (\%) } & \multicolumn{3}{|c|}{ Susceptibility Class } \\
\hline & & & 1 (Low) & 2 (Moderate) & 3 (High) \\
\hline 1 & Slope inclination & 30 & $\begin{array}{l}\text { Slope inclination }< \\
21 \% \text {, relatively flat } \\
\text { to moderate relief }\end{array}$ & $\begin{array}{l}\text { Slope inclination } 21 \% \text { - } \\
55 \% \text {, moderate to steep } \\
\text { relief }\end{array}$ & $\begin{array}{l}\text { Slope inclination }>55 \% \text {, } \\
\text { steep to very steep relief }\end{array}$ \\
\hline 2 & Soil cover & 15 & $\begin{array}{l}\text { Slope is composed } \\
\text { of sandy soils. There } \\
\text { is sharp contrast } \\
\text { between the soils } \\
\text { and underlying } \\
\text { rocks }\end{array}$ & $\begin{array}{l}\text { Slope is composed of clay } \\
\text { soils. There is no sharp } \\
\text { contrast between the soils } \\
\text { and underlying rocks }\end{array}$ & $\begin{array}{l}\text { Slope is composed of } \\
\text { clay soils. There is sharp } \\
\text { contrast between the } \\
\text { soils and underlying } \\
\text { rocks }\end{array}$ \\
\hline 3 & Rock slope & 20 & $\begin{array}{l}\text { Slope is composed } \\
\text { of soils and } \\
\text { unfractured rocks. }\end{array}$ & $\begin{array}{l}\text { Slope is composed of a } \\
\text { number of fractured rocks. } \\
\text { The rock discontinuities } \\
\text { are not daylight }\end{array}$ & $\begin{array}{l}\text { Slope is composed of } \\
\text { highly fractured rocks }\end{array}$ \\
\hline 4 & Rainfall & 15 & $\begin{array}{l}\text { Rainfall intensity }< \\
30-70 \mathrm{~mm} / \mathrm{h}, \\
\text { duration }<2 \mathrm{~h} \text {, and } \\
\text { annual rainfall }< \\
1000 \mathrm{~mm}\end{array}$ & $\begin{array}{l}\text { Rainfall intensity } 30-70 \\
\mathrm{~mm} / \mathrm{h} \text {, duration }<2 \mathrm{~h} \text {, } \\
\text { and annual rainfall } 1000- \\
2500 \mathrm{~mm}\end{array}$ & $\begin{array}{l}\text { Rainfall intensity } 70 \\
\mathrm{~mm} / \mathrm{h} \text { or } 100 \mathrm{~mm} / \mathrm{d} \text {, } \\
\text { annual rainfall }>2500 \\
\mathrm{~mm}\end{array}$ \\
\hline 5 & Seepage & 7 & $\begin{array}{l}\text { No seepages or } \\
\text { springs at the } \\
\text { contact between } \\
\text { impermeable rocks } \\
\text { and permeable soils }\end{array}$ & $\begin{array}{l}\text { A small number of } \\
\text { seepages or springs at the } \\
\text { contact between } \\
\text { impermeable rocks and } \\
\text { permeable soils }\end{array}$ & $\begin{array}{l}\text { A large number of } \\
\text { seepages or springs at } \\
\text { the contact between } \\
\text { impermeable rocks and } \\
\text { permeable soils }\end{array}$ \\
\hline 6 & Earthquake & 3 & $\begin{array}{l}\text { Slope is not in the } \\
\text { area susceptible to } \\
\text { earthquake }\end{array}$ & $\begin{array}{l}\text { Earthquake occurs } \\
\text { infrequently ( } 1-2 \text { events } \\
\text { per year) }\end{array}$ & Earthquake area \\
\hline 7 & Vegetation & 10 & $\begin{array}{l}\text { Tress with strong } \\
\text { and deep roots }\end{array}$ & $\begin{array}{l}\text { Trees having needle-like } \\
\text { leaves }\end{array}$ & $\begin{array}{l}\text { Coarse grasses, weeds, } \\
\text { and scrubs }\end{array}$ \\
\hline
\end{tabular}

of susceptibility to landslide. The vegetation existing in the research area consisted of trees having needle-like leaves and coarse grasses, weeds, and scrubs, and could be categorized into moderate and high classes of susceptibility to landslide, respectively. Meanwhile, the conditions of rainfall, seepage, and earthquake frequency were relatively uniform in the research area. The annual rainfall in the Cimanuk Watershed ranged from $1900 \mathrm{~mm}$ to $4200 \mathrm{~mm}$ (PT. Indra Karya Consulting Engineer, 2013) and, therefore, the parameter in the research area could be classified into a moderate class of susceptibility to landslide. No seepage or spring was observed in the research area and, therefore, the parameter could be classified into a low class of susceptibility to landslide. The earthquake in the research area had been relatively infrequently (Sobirin, 2005; Jones et al., 2014) and the parameter could be classified into a moderate class of susceptibility to landslide.

A total susceptibility index was calculated by summing the susceptibility indices of all parameters using the overlay method in the geo- graphic information system (GIS). The total susceptibility index of 1.00 to $1.69,1.70$ to 2.39 , and 2.40 to 3.00 indicated low, moderate, and high classes of susceptibility to landslide, respectively. The engineering geological characteristics, particularly the morphology, engineering properties of the soil cover and rock, geological structure, susceptibility to landslide, and land use, of the areas to the west and to the east of the embankment dam were then compared qualitatively for determination of the most suitable location for of the emergency spillway construction.

\section{Results and Discussions}

The area surrounding the Jatigede Dam is characterized by hilly, slope, and river valley morphologies with slope inclination ranging from 0 to $140 \%$. Figure 1 shows the map of slope inclination in the research area that was classified following van Zuidam and van ZuidamCancelado (1979). The dam reservoir had not been filled when the research was conducted 


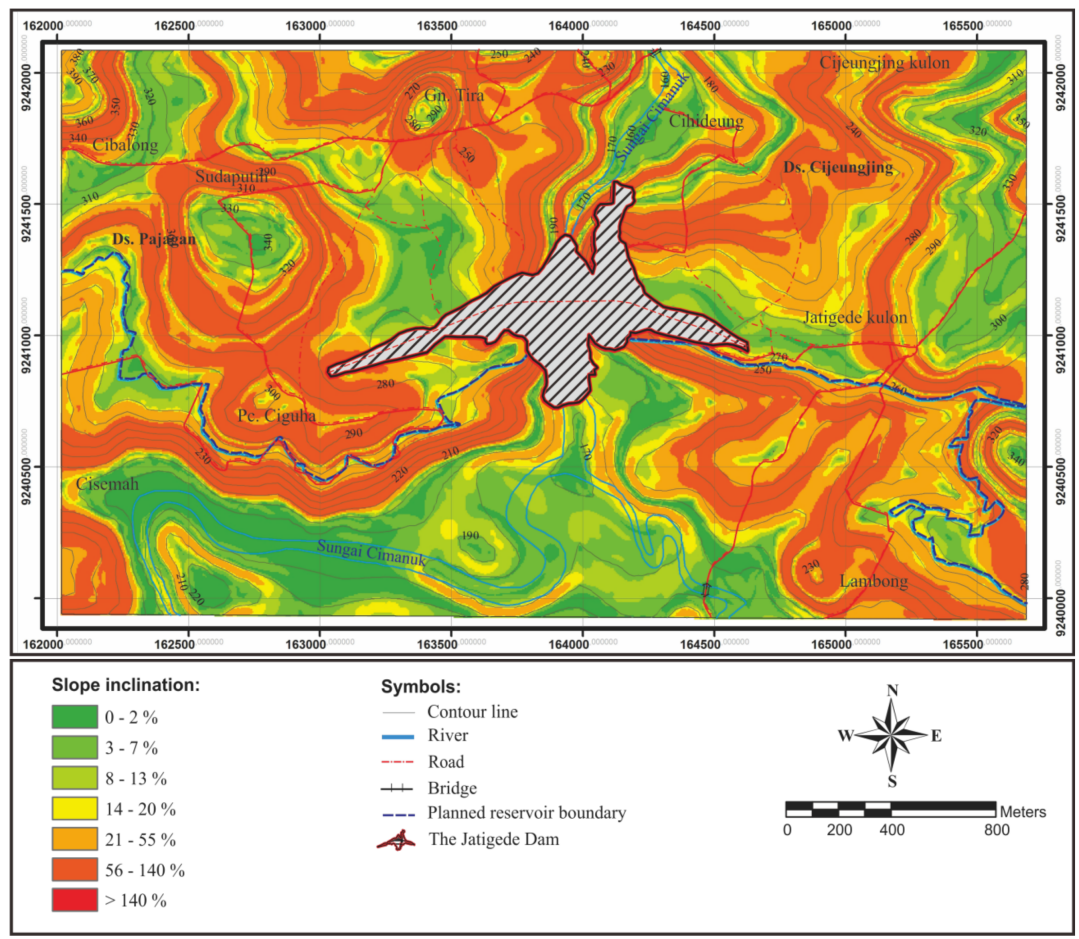

Figure 1: Slope inclination map of the research area.

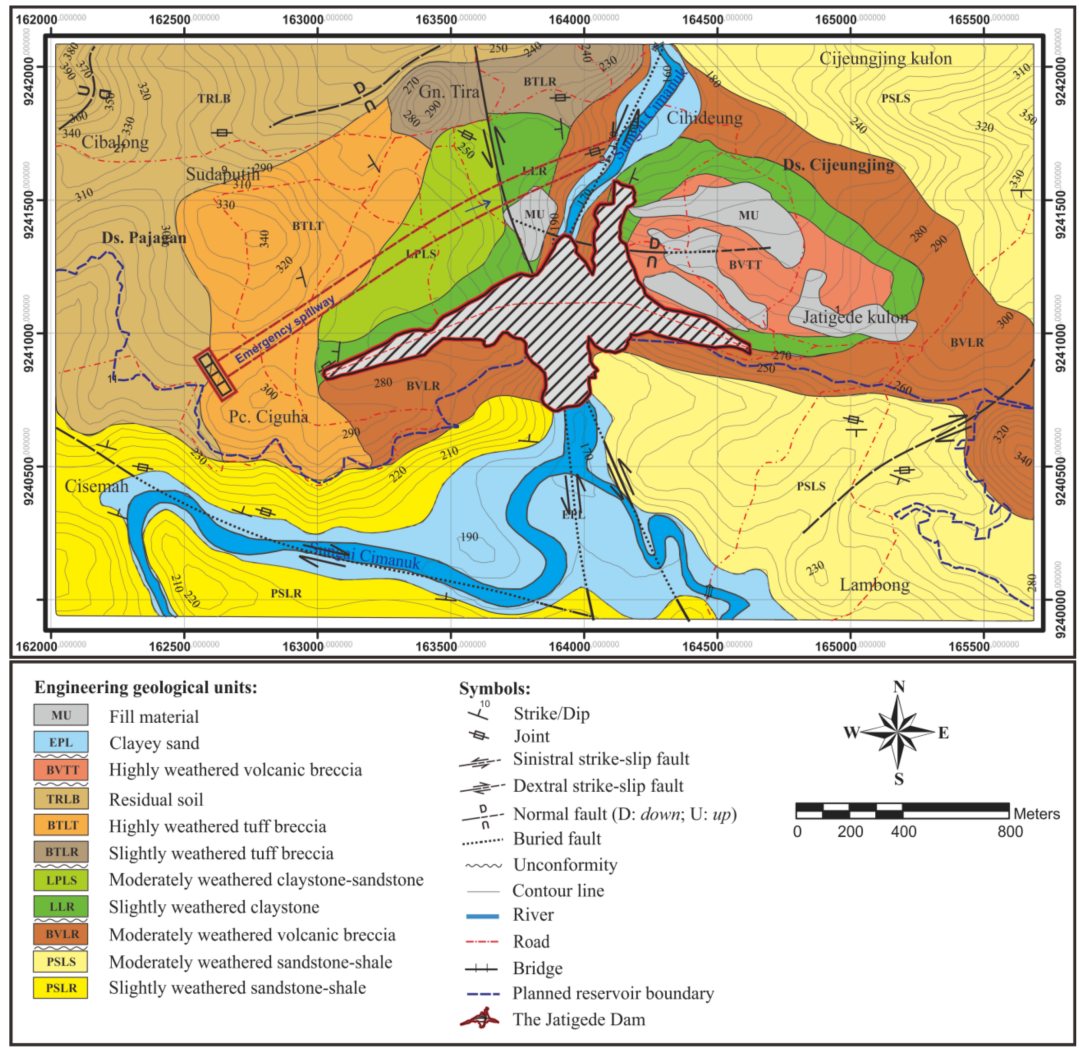

Figure 2: Engineering geological map of the research area. 
and the blue dash line lies to the south of the embankment dam shown in the map is the planned reservoir boundary. In the area to the west of the embankment dam, the slope inclination ranged from 3 to $20 \%$, while in the area to the east of the embankment dam, the slope inclination ranged from 14 to $55 \%$. With respect to the topography, an emergency spillway constructed in the area to the east of the embankment dam will likely suffer more severe erosion that that in the area to the west of the embankment dam due to a higher hydraulic gradient. Erosion of unlined earthen emergency spillway may cause failure of spillway structures and catastrophic release of reservoir waters, spillway channel bank failure, and sedimentation in the spillway exit and main channel (Cameron et al., 1990).

The engineering geological units composing the research area are shown in Figure 2 The sandstone intercalated with shale of the Cinambo Formation exposed in the areas to the south and north-east of the embankment dam could be distinguished into the slightly weathered sandstone-shale (PSLR) and moderately weathered sandstone-shale (PSLS) unit (Figure 3). Both units were highly fractured. The slightly weathered sandstone-shale unit had a $36.9-108.9 \mathrm{kgf} / \mathrm{cm}^{2}$ unconfined compression strength (UCS) value (Makmur, 2009). The moderately weathered volcanic breccia (BVLR) unit of the Lower Part of the Halang Formation, which was largely exposed in the area to the east of the embankment dam, was highly fractured and had a $60-95 \%$ rock quality designation (RQD) value and a 69.1-127.2 kgf $/ \mathrm{cm}^{2} \mathrm{UCS}$ value (Makmur, 2009) (Figure 4a). The slightly weathered claystone (LLR) unit of the Upper Part of the Halang Formation, which was exposed in the areas to the north-east and northwest of the embankment dam, and the moderately weathered claystone-sandstone (LPLS) unit of the Upper Part of the Halang Formation, which was exposed in the area to the north-west of the embankment dam, were also fractured (Figure $4 \mathrm{p}$ and Figure $4-\mathrm{d}$ ). The claystone unit is essentially impermeable to water flow. Due to weathering and fracturing, however, the rock unit generally had up to 5 Lugeon permeabil-

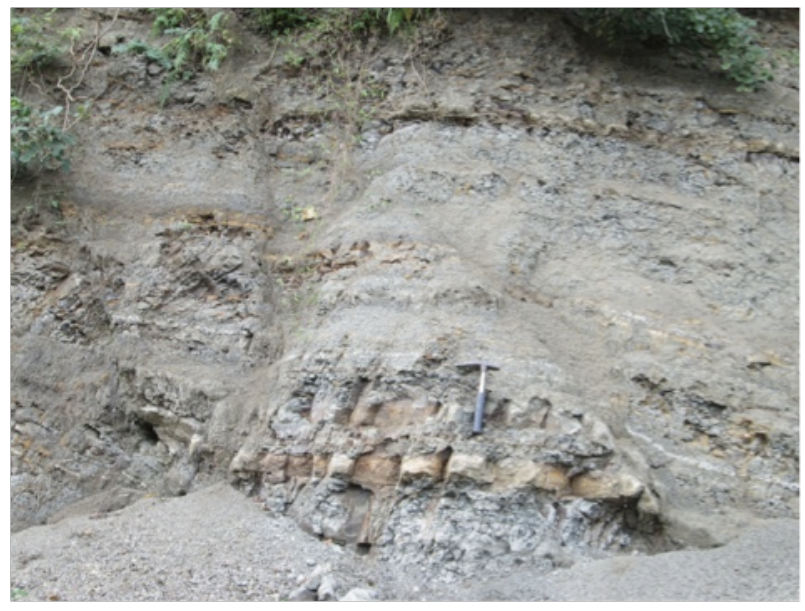

Figure 3: Moderately weathered and fractured sandstone-shale (LPLS) of the Cinambo Formation.

ity value (Makmur, 2009). The slightly weathered tuff breccia (BTLR) and highly weathered tuff breccia (BTLT) units of the Folded Breccia Formation exposed in the area to the west of the embankment dam had a 0-100 Lugeon permeability value, where the upper range of permeability value was the characteristics of the highly fractured and weathered tuff breccia unit (Makmur, 2009) (Figure 4). The residual soil (TRLB) unit in the top left corner of the map was essentially a weathering product of the tuff breccia of the Folded Breccia Formation and had up to a $40 \mathrm{kgf} / \mathrm{cm}^{2}$ UCS value (Makmur, 2009). The clayey sand (EPL) unit of the unconsolidated Alluvial and Talus Deposits was exposed in the area along the river. The fill material (MU) unit located to the east of the embankment dam partly covered the area underlain directly by the highly weathered volcanic breccia (BVTT) unit of the Undifferentiated Old Volcanic Products (Figure $4 \mathrm{f}$ ). The fill material (MU) unit was essentially a geogrid reinforced soil and a graded soil foundation of gabion gravity retaining walls for slope stabilization and erosion control. The earth retaining structures were installed in the area composing of the highly weathered volcanic breccia (BVTT) unit because the area had been very susceptible to landslide, as discussed in the paragraph of landslide susceptibility zoning below.

An emergency spillway to be constructed 

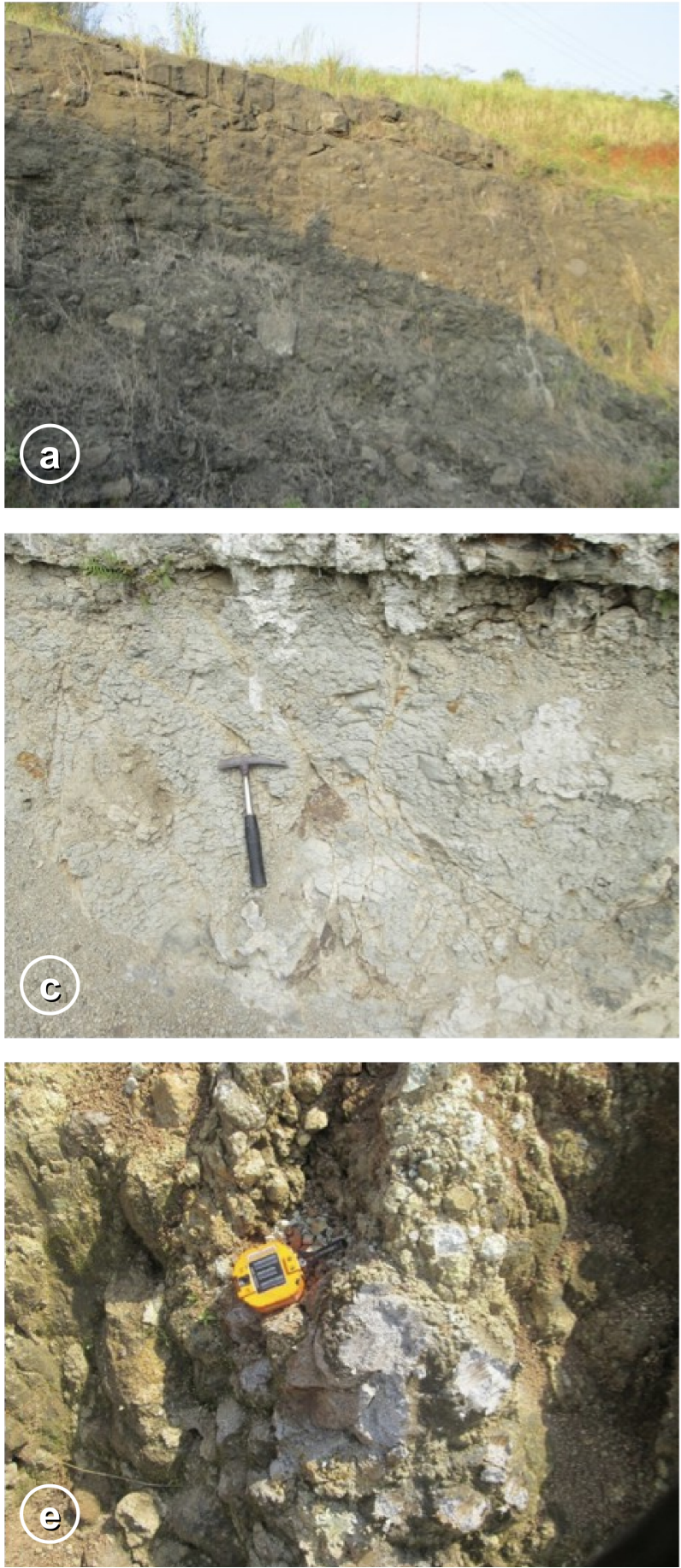
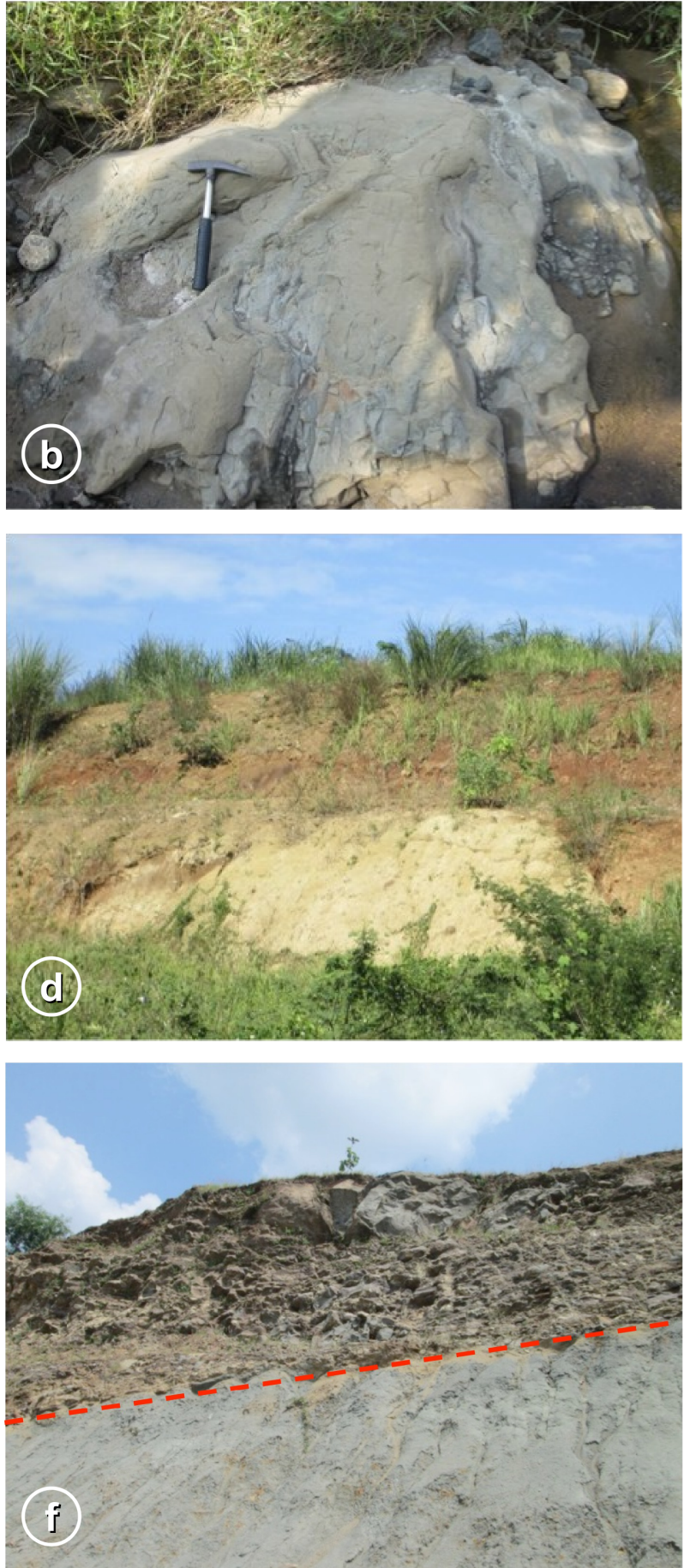

Figure 4: a) Moderately weathered volcanic breccia (BVLR) of the Lower Part of the Halang Formation. b) Slightly weathered and fractured claystone (LLR) of the Upper Part of the Halang Formation. c) Moderately weathered and fractured claystone. d) Moderately weathered tuffaceous sandstone (bottom) of the claystone-sandstone (LPLS) of the Upper Part of the Halang Formation. e) Highly weathered tuff breccia (BTLT) of the Folded Breccia Formation. f) Highly weathered volcanic breccia (BVTT) of the Undifferentiated Old Volcanic Products on top of slightly weathered claystone (LLR) of the Upper Part of the Halang Formation. 
in the area to the west of the embankment dam will likely cut through the highly weathered tuff breccia (BTLT), moderately weathered claystone-sandstone (LPLS), and slightly weathered claystone (LLR) units. The highly weathered tuff breccia (BTLT) unit will likely be vulnerable to erosion by flood water. Meanwhile, an emergency to be constructed in the area to the east of the embankment dam will likely cut through the slightly weathered claystone (LLR), highly weathered volcanic breccia (BVTT), and fill material (MU) units. The highly weathered volcanic breccia (BVTT) and fill material (MU) units will likely be vulnerable to erosion by flood water. Although both areas composed of less erosion resistant rock units, the existence of fill material (MU) units and the earth retaining structures in the area to the east of the embankment dam will likely limit the flexibility in developing the emergency spillway route. In other words, the area to the west of the embankment dam is more favorable for construction of the emergency spillway.

Figure 2 also shows a number of faults existing in the research area, including the large north-south strike-slip faults along the Cimanuk River and perpendicular to the embankment dam. With respect to the existence of fault systems, both areas to the west and to the east of the embankment dam will likely be influenced by similar conditions. Although the existing faults in the research area are not active faults (PT. Indra Karya Consulting Engineer, 2013), caution must be taken when an unlined emergency spillway to be constructed crossing the strike-slip fault at the contact between the slightly weathered claystone (LLR) and moderately weathered claystone-sandstone (LPLS) units in the area to the west of the embankment dam or crossing the normal fault cutting the highly weathered volcanic breccia (BVTT) unit of the Undifferentiated Old Volcanic Products in the area to the east of the embankment dam since the fault zones may induce uncontrolled seepage.

Figure 5 shows the landslide susceptibility zones in the research area. In general, the result of the landslide susceptibility zoning obtained from this research is in a reasonably agreement with the Regional Map of Landslide Susceptibility Zone of Arjawinangun Sheet (Sugalang and Sugiyanto, 1994), which indicates that the Jatigede area is located in the moderate to high susceptibility to landslide. The hilly areas of the research area are characterized by a moderate to high class of susceptibility to landslide, while the river valleys are characterized by a low class of susceptibility to landslide. Figure 5 also shows that the previous landslides occurred mainly in the high susceptibility zones, implying a reasonably high accuracy of landslide prediction using the adopted method. The slope inclination and material engineering properties appear to dominantly control the susceptibility of the research area to landslide.

In the area to the west of the embankment dam, the relatively steep slopes along the Cimanuk River were highly susceptible to landslide (Figure 5). Meanwhile, in the area to the east of the embankment dam, the hilly area composed of the highly weathered volcanic breccia (BVTT) unit of the Undifferentiated Old Volcanic Products was highly susceptible to landslide. Landslide may cause damage to the emergency spillway structure or block the emergency spillway channel and those two zones of high susceptibility to landslide should be avoided for construction of the emergency spillway. However, since the area to west of the embankment dam had relatively a smaller number of landslide cases and less area of high susceptibility to landslide than the area to the east of the embankment dam, the area to west of the embankment dam is likely more favorable for construction of the emergency spillway.

Figure 6 shows a map of the existing land uses in the research area that consisted of a grassland, mixture of residential and commercial land, agriculture land, plantation land, forest land, and barren land. The main access road from a nearby city (i.e., Cirebon) to the embankment dam passed through the residentialcommercial zone, which was located to the east of the embankment dam. An access road to the area to the west of the embankment dam was provided through the top of the embankment dam. Since the area to the west of the embankment dam was undeveloped, therefore, 


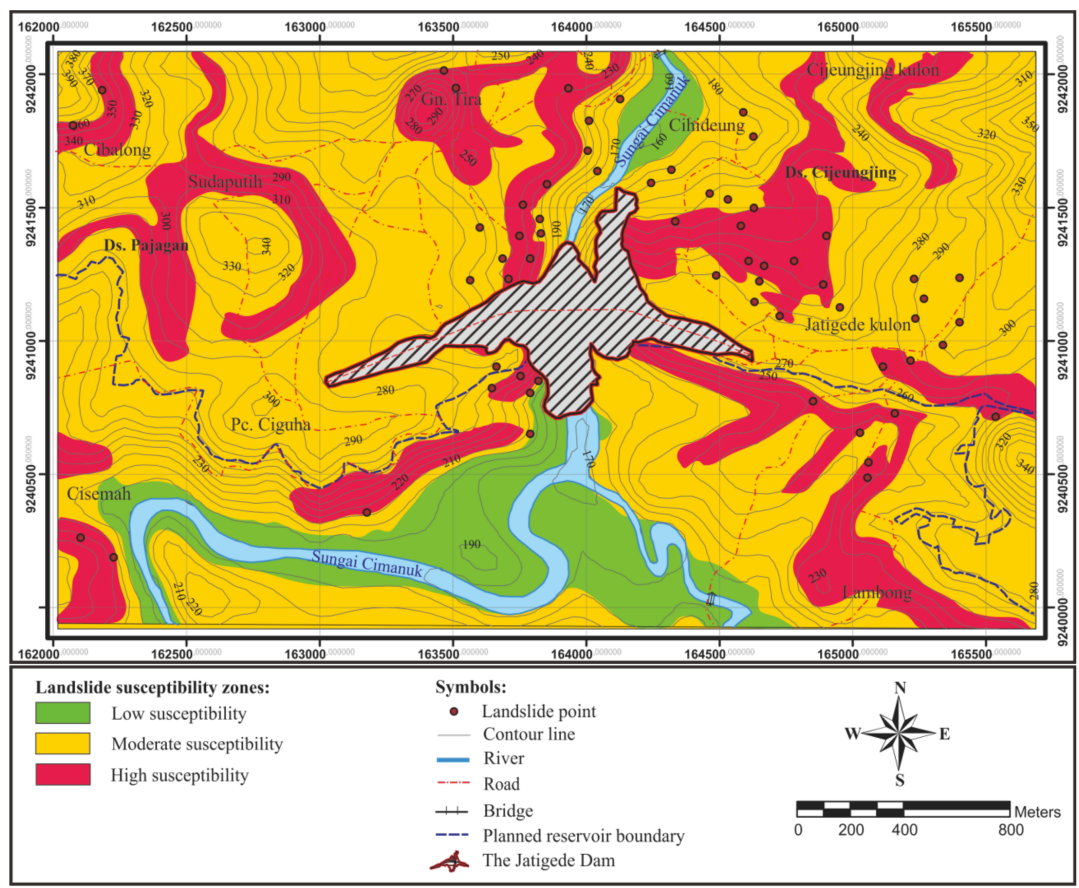

Figure 5: Landslide susceptibility map of the research area.

the area to the west of the embankment dam provided more flexibility in construction of the emergency spillway.

Considering the more favorable engineering geological characteristics, particularly the morphology, engineering properties of the soil cover and rock, geological structure, susceptibility to landslide, and land use, the emergency spillway is, therefore, proposed to be constructed in the area to the west of the embankment dam, as shown in Figure 2 The nearly straight emergency spillway route is expected to take the flood water shortly to the Cimanuk River downstream behind the embankment dam.

\section{Conclusions}

A site investigation involving an engineering geological mapping and landslide susceptibility zoning was conducted to determine the engineering geological characteristics of the areas to the west and to the east of the Jatigede Dam. The area to the west of the embankment dam tended to have a lower slope inclination than the area to the east of the embankment dam. Both areas to the west and to the east of the em- bankment dam were found to be composed of less erosion resistant rock units. However, the existence of the earth retaining structures for slope stabilization in the area to the east of the embankment dam will likely limit the flexibility in developing the emergency spillway route. With respect to the existence of fault systems, both areas to the west and to the east of the embankment dam will likely be influenced by similar conditions. The area to the west of the embankment dam tended to be less susceptible to landslide as compared to the area to the east of the embankment dam. The undeveloped land use of the area to the west of the embankment dam as compared to the area to the east of the embankment dam will provide more flexibility in construction of the emergency spillway. Considering the more favorable engineering geological characteristics, particularly the morphology, engineering properties of the soil cover and rock, geological structure, susceptibility to landslide, and land use, the area to the west of the embankment dam is, therefore, proposed for the location of the emergency spillway. 


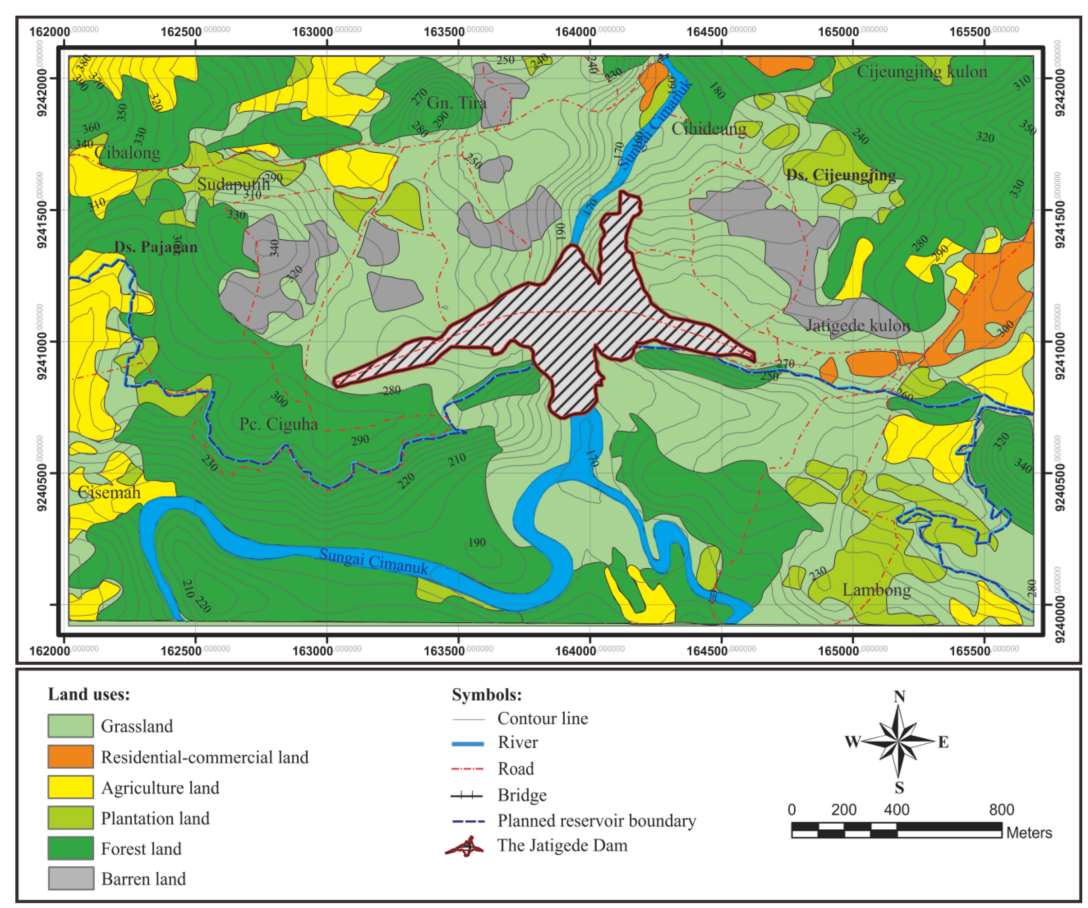

Figure 6: Land use map of the research area.

\section{Acknowledgements}

The research was supported by Department of Geological Engineering Universitas Gadjah Mada and Balai Besar Wilayah Sungai (BBWS) Cimanuk-Cisanggarung. The first author wishes to thank the BBWS CimanukCisanggarung for the opportunity to do the research. The assistance of Mr. Dwi Agus Kuncoro and Mr. Anwar Makmur of the BBWS Cimanuk-Cisanggarung is gratefully acknowledged.

\section{References}

Cameron, C.P., Patrick, D.M., May, J.H., Palmerton, J.B., McAneny, C.C., Hatheway, A.W., Bartholomew, C.O., Mathewson, C.C., and Cato, K.D. (1990) Geotechnical Aspects of Rock Erosion in Emergency Spillway Channels. Report 5: Summary of Results, Conclusions, and Recommendations. US Army Corps of Engineers.

Departemen Pekerjaan Umum (2007) Pedoman Penataan Ruang Kawasan Rawan Bencana Longsor. Peraturan Menteri Pekerjaan Umum No.22/PRT/M/2007. Departemen
Pekerjaan Umum, Direktorat Jenderal Penataan Ruang, Jakarta, p.15-43.

Djuri (1995) Peta Geologi Lembar Arjawinangun, Jawa Barat, Skala $1: 100.000$. Direktorat Geologi Bandung, Bandung.

Jones, E.S., Hayes, G.P., Bernardino, M., Dannemann, F.K., Furlong, K.P., Benz, H.M., Villasenor, A. (2014) Seismicity of the Earth 1900-2012 Java and Vicinity, U.S. Department of the Interior, U.S. Geological Survey, OpenFile Report 2010-1083-N.

ISRM (1981) Basic Geotechnical Description of Rock Masses. International Journal of Rock Mechanics Mining Sciences and Geomechanics Abstracts, 18, pp. 85-110.

Makmur, A. (2009) Rock Foundation Excavation in Case at Jatigede Dam. A Project Report, p. 2-4.

Makmur, A. (2013) Pengaruh Struktur Geologi Terhadap Mutu Batuan Pondasi Bendungan Jatigede. SNVT Pembangunan Waduk Jatigede, Direktorat Jenderal Sumber Daya Air, Kementerian Pekerjaan Umum, Sumedang, p. 2-15.

Novak, P., Moffat, A.I.B., Nalluri, C., and Narayanan, R. (2007) Hydraulic Structures. Taylor and Francis. 
PT. Indra Karya Consulting Engineer (2013) Pemantauan dan Kajian Penggenangan Waduk Jatigede (Paket 30). Laporan Triwulan: Kementerian Pekerjaan Umum, Direktorat Jenderal Sumber Daya Air, Balai Besar Wilayah Sungai Cimanuk-Cisanggarung, Sumedang.

Sobirin (2005) Penolakan Pembangunan Waduk Jatigede dan Pemulihan DAS di Jawa Barat, DPKLTS, Bandung.

Sugalang, U.B. dan Sugiyanto (1994) Peta Zona Kerentanan Gerakan Tanah Daerah Arjawinangun dan Sekitarnya, Jawa Barat, Skala 1 :
100.000, Direktorat Vulkanologi dan Mitigasi Bencana Geologi, Bandung.

van Bemmelen, R.W. (1970) The Geology of Indonesia Vol. 1 A. General Geology of Indonesia and Adjacent Archipelagoes, $2^{\text {nd }}$ ed., Government Printing Office, The Hauge, Amsterdam, p. 645-653.

van Zuidam, R.A. and van Zuidam-Cancelado, F.I. (1979) Terrain Analysis and Classification using Aerial Photographs, International Institute for Aerial Survey and Earth Science, Netherlands. 